Bay of Biscay

http://dx.doi.org/10.1016/i.csr.2008.12.017

(c) 2009 Elsevier Ltd All rights reserved.

\title{
Development of a hydrodynamic model of the Bay of Biscay. Validation of hydrology
}

\author{
Pascal Lazure $^{\mathrm{a},{ }^{*}}$, Valérie Garnier ${ }^{\mathrm{a}}$, Franck Dumas ${ }^{\mathrm{a}}$, Christelle Herry $^{\mathrm{b}}$ and Marina Chifflet $^{\mathrm{a}}$ \\ a Ifremer centre de Brest, BP 70, 29280 Plouzané, France \\ ${ }^{\text {b }}$ Actimar, Quai de la douane, 29280 Brest, France \\ *: Corresponding author : Pascal Lazure, email address : Pascal.Lazure@ifremer.fr
}

\begin{abstract}
:
The hydrology of the Bay of Biscay was investigated using the regional ocean model MARS3D (Model for Application at Regional Scale). The simulated hydrology is compared to a set of various data encompassing monthly climatology, remote sensing SST, CTD casts, and coastal salinity measurements. Special focus was put on the validation over the continental shelf. This paper reports that despite some misfits, the climatological hydrology and its seasonal variability are correctly simulated. Various statistics computed over the period from 1999-2004 highlight different aspects of the hydrology. The biases and root mean square errors (RMSE) remain very weak at all depths when comparing salinity $(<0.1$ and $<0.6 \mathrm{psu}$ respectively). The predicted temperature shows a global overestimation of temperature (bias of around $0.8^{\circ} \mathrm{C}$ ) and the maximum errors are located near the thermocline (rmse of $1^{\circ} \mathrm{C}$ at $20-40 \mathrm{~m}$ ). The model is shown to properly reproduce the annual dynamics of sea surface temperature, as well as the dynamics of large river plumes observed by high frequency time series from coastal salinity gauges. The misfits highlighted by these various comparisons between model and observations are attributed to heat fluxes and mixing parameterisation.
\end{abstract}

Keywords: Bay of Biscay; Regional model; Performance assessment 


\section{Introduction}

The Bay of Biscay (Figure 1) is a semi-enclosed sea bounded by the French Atlantic coast to the east and the northern coast of Spain to the south. It is connected to the north-east Atlantic Ocean to the West and to the Celtic sea to the North. It is a complex oceanic domain divided into two parts by a shelf break. The abyssal plain is more or less semi-circular with depths of about $4,000 \mathrm{~m}$. The continental shelf is very narrow along the Spanish coast and off the French Basque country. It widens going northwards, reaching about $200 \mathrm{~km}$ at the entrance of the English Channel. The Bay of Biscay supports a large number of activities: tourism and shellfish farming along the coasts and intensive fisheries over the shelf and along the slopes. Sustainable development of these activities requires good knowledge of the environment, including its hydrodynamics, hydrology and ecosystem especially in view of increasing issues like water pollution as seen in repeated oil spills : Erika in December 1999 (Laubier et al,. 2004) or Prestige in November 2002 (Gonzalez et al., 2008), harmful algal blooms leading to closures of the shellfish market and sharply dwindling stocks of small pelagic fish (like anchovies). These concerns require new skills and tools in order to understand and protect the global ecosystem. They have recently given rise to the development of an operational system in the Iberian-Biscay zone within the Ibiroos project (Pouliquen and Lavin, 2006).

Bay dynamics are complex and heterogeneous. In the abyssal part, the circulation is rather weak with typical velocities of few centimetres per second (see Pingree and Le Cann, 1989, for instance). The tidal wave enters the bay from the open Atlantic (Pairaud et al., 2006), crosses the shelf break in an orthogonal direction and then is largely amplified over the shelf. The tide in the presence of stratification, is responsible for large internal tidal waves (New, 1988) propagating from the break towards the shelf and the abyssal plain. At the shelf break, it is responsible for strong vertical mixing whose signature goes up to the surface. Over the French shelf, the tide plays a major role in mixing of water masses which creates thermal fronts (Le Boyer et al., 2008), and locally, intense residual currents, in north Brittany (Salomon and Breton, 1993).

The hydrology of the continental shelf of the Bay of Biscay is complex and highly variable. Numerous studies have described temperature and salinity trends along the Spanish slope, as for example, two recent studies describing the hydrology over the last decade (Cabanas et al., 2003 and Lloppe et al., 2006). The first comprehensive studies over the French continental shelf were performed in the late sixties (Vincent and Kurc, 1969). Koutsikopoulos and Le Cann (1996) gave a seasonal description of the main hydrological structures over the shelf. This view has been further broadened by Puillat et al. (2004), amongst others, who provided a description of the hydrology and its variability in the nineties. The main aspects can be summarised as follows: thermal stratification occurs between May and October over the shelf. The thermocline depth varies from 20 to $50 \mathrm{~m}$. Some local thermal fronts appear during spring and summer. In the north of the Bay, the Ushant front is induced by tidal mixing (Le Boyer et al, 2008). In the south, along the Landes coast or along the Spanish coast, transient upwellings induce thermal fronts (Froidefond et al, 1996). In autumn, a surface warm tongue extends from the Basque country to South Brittany and is centred over the $100 \mathrm{~m}$ isobath. It could be linked to the poleward circulation during autumn as suggested by Lazure et al (2008). Conversely, a cold coastal strip appears in winter and early spring. This cold water is correlated with small depths and the salinity pattern. Indeed, the Bay of Biscay is characterised by large amounts of fresh winter inputs, mainly from the Loire and Gironde rivers, with annual average run offs of $900 \mathrm{~m}^{3} \mathrm{~s}^{-1}$. As shown by Lazure and Jegou (1998), the river plumes on the shelf exhibit strong seasonal variability induced by runoff (minimum at the end of summer, maximum in winter) and the prevailing wind regime. In autumn and winter, the river plumes remain near the coast and spread polewards. In spring, the upwelling-favourable winds spread the river plumes over the shelf and in the southern part of the Bay. As shown by Puillat et al. 2006, this pattern is highly variable each year, depending on the variability of both runoff and winds. 
This view taken from in situ measurements is enriched by hydrodynamic models of the Bay of Biscay. Some models have focused on the continental shelf and others have been devoted to studying various processes. Le Cann (1990) and Pairaud et al. (2008a) described the main features of tides over the shelf. Pichon et al. (2006) and Pairaud et al. (2008b) focused on the internal tides generated along the slope. Pingree et al., (1982) highlighted the role of tidal mixing on temperature distribution. Lazure and Jegou (1998) described the salinity distribution over the Aquitaine and Armorican shelf under the influence of the main river discharges. Recently, Friocourt et al. (2007) presented an OPA model application describing the circulation and its variability over the abyssal plain and the shelf break.

This paper aims at validating the simulations with the MARS3D model of the hydrology of the Bay of Biscay under realistic conditions by comparing them with in situ (CTD casts, continuous temperature and salinity series from coastal probes) and remotely-sensed data (AVHRR SST), over half a decade (1999-2004). We have mainly focused our attention on the shelf. The goal is to simulate the seasonal to interannual variability and quantify the errors in order to use this model for scientific purposes and in an operational context. To our knowledge, this paper is the first assessment of the reliability of predicted hydrology over the French continental shelf in the Bay of Biscay.

Following Crosnier and le Provost (2007), we first assessed the consistency of the model by comparing simulated and in situ climatological data (Vandermeirsch et al 2008). We sought good agreement between model results and the main hydrological structures as described by Koutsikopoulos and Le Cann (1996) in terms of location, shape and strength over the shelf. Then, we performed a more quantitative validation by comparing model results and in situ colocalised observations of temperature and salinity. We evaluated different statistics (bias, and root mean square errors). However, to overcome the lack of synopticity of in situ observations, we used satellite Sea Surface Temperature (SST) measurements and compared them with predictions. This allows comparison over long periods (several years) affected by the variability from seasonal to interannual scales. Finally, we used time series of coastal salinity measurements to assess the ability of the model at reproducing the variability of salinity induced by river plumes and their fate over the shelf.

\section{Model description}

The kernel of the MARS3D (Model for Application at Regional Scale) model has been fully described by Lazure and Dumas (2008). It is a finite difference, mode splitting model with novel coupling of the barotropic-baroclinic modes within a sigma-coordinate framework.

The model extends from $8^{\circ} \mathrm{W}$ to the French Atlantic coast and from the Spanish coast to $50^{\circ} 30^{\prime} \mathrm{N}$ thus encompassing the entrance of the English Channel. The eastern boundary in the Channel is set at $3^{\circ} \mathrm{W}$. The horizontal resolution is $4 \mathrm{~km}$ and 30 vertical levels are considered and refined near the surface, the grid spacing in sigma coordinate corresponds to a resolution of $0.15 \mathrm{~m}$ at the surface and $3.5 \mathrm{~m}$ in the middle of a $100 \mathrm{~m}$ water column.

The application to the Bay of Biscay described in by Lazure and Dumas (2008) showed that the tide is accurately simulated. The differences between observed and simulated sea levels do not exceed $0.1 \mathrm{~m}$. Comparison with current profile records gives acceptable agreement for short time ranges when tidal currents prevail.

Some details about the heat budget calculation and turbulence closure scheme not described in Lazure and Dumas (2008) are given here, since they play a determining role in temperature prediction. 


\section{$\underline{\text { Heat fluxes }}$}

The air-sea heat exchanges were parameterised as in Luyten and De Mulder (1992) and implemented as in COHERENS (Luyten et al, 1999). The set of parameterisations can be summarised as follows:

- $\quad$ for the latent heat flux :

$$
Q_{\text {lat }}=\rho_{a} L_{a} C_{E}\left\|W_{10}^{\mathrm{LuW}}\right\|\left(q_{s}-q_{a}\right)
$$

Where $\rho_{a}$ is the air density, $\left\|W_{10}\right\|$ the wind speed at $10 \mathrm{~m}$ above sea surface, $\mathrm{q}_{\mathrm{s}}, \mathrm{q}_{\mathrm{a}}$, the relative humidity at the surface and at $2 \mathrm{~m}, \mathrm{~L}_{\mathrm{a}}$ the latent heat of vaporisation and $\mathrm{C}_{\mathrm{E}}$ the Dalton number set to $1.1310^{-4}$. The wind speed is experimentally increased by $25 \%$ in this expression. This point will be discussed later.

- for the sensitive heat flux :

$$
Q_{\text {sens }}=\rho_{a} C_{p a} C_{H}\left\|W_{10}^{\text {Lum }}\right\|\left(T_{s}-T_{a}\right)
$$

Where $C_{p a}$ is the specific heat of air at constant pressure, $\mathrm{T}_{\mathrm{s}}$ and $\mathrm{T}_{\mathrm{a}}$ are the sea surface and air temperature at $2 \mathrm{~m}$ and $\mathrm{C}_{\mathrm{H}}$ the Stanton number set to $1.1310^{-4}$.

- $\quad$ for the long wave component of the flux we followed Gill (1982) :

$$
Q_{l w}=\varepsilon_{s} \sigma_{r a d}\left(T_{s}+273.15\right)^{4}\left(0.39-0.05 e_{a}^{1 / 2}\right)\left(1-0.6 f_{c}^{2}\right)
$$

Where $f_{c}$ is the fractional cloud cover, $e_{a}$ is the vapour pressure, $\varepsilon_{\mathrm{s}}$ and $\sigma_{\text {rad }}$ are respectively the emissivity of the sea surface and Stefan's constant.

the short wave flux is derived by Reed (1977)

$$
Q_{\text {rad }}=Q_{c s}\left(1-0.62 f_{c}+0.0019 \Gamma\right)(1-A)
$$


Where $Q_{c s}$ is the clear sky radiation, $\Gamma$ stands for the solar altitude at noon and the surface albedo, $A$, is set to fit the empirical approximation by Payne (1972) (i.e. $A=0.06$ )

The air temperature, wind speed, fraction cloud cover and relative humidity used by the bulk formulae expressed above are provided by the Arpege model of Météo France. This model has a spatial resolution of $0.5^{\circ}$ both in latitude and longitude and provides an analysis every 6 hours. Both spatial and temporal interpolations are then performed on the spatial grid of MARS at each time step.

The short wave radiation penetrates the surface layer according to an exponential law, $Q(z)=Q(0) \exp (-\lambda z)$, whose extinction coefficient is taken as being constant over space and time $\left(\lambda=0.1 \mathrm{~m}^{-1}\right), \mathrm{z}$ is the positive downward distance below the surface. In order to avoid unrealistic summer warming in shallow water areas where the residence time is long, the heat flux not absorbed in the water column and reaching the bottom is considered as lost. This assumption was used by Holt and James (1999) in the North Sea for the same reasons.

\section{$\underline{\text { Turbulence closure scheme }}$}

The turbulence closure scheme is based on the equation of evolution of the turbulent kinetic energy (Gaspar et al., 1990).

Horizontal turbulent diffusion is computed according to the formulation of Smagorinsky (1963). The free parameter in its formulae is taken to be: 0.27 , the lowest possible coefficient to ensure the numerical stability. This value is close to the value of 0.2 which seemed to give satisfactory results in a study of baroclinic eddies on the shelf seas west of Great Britain (Holt and James, 2006).

\section{Open boundary conditions and sponge layers.}

The temperature, salinity, free surface elevation ( $\mathrm{SSH}$ : sea surface height above the geoid) and currents at open boundaries are provided by the global ORCA025 simulation which is an application of the NEMO model (Madec 2008). The global ORCA025 aimed to reproduce global circulation and hydrology over the last decades. The tide is not taken into account in this model, so tidal boundary conditions (sea levels and currents) are provided by another large scale model and linearly added to ORCA's solution (see the next paragraph). ORCA025 is a 0.25 degree resolution simulation which differs slightly from that described by Barnier et al (2006), mostly by its surface forcing (described in Michel et al, 2008, this issue). In this application, we used the monthly means of ORCA's solution for temperature, salinity, sea surface heights and currents. Each of these quantities was estimated at the computational grid nodes with a spatial interpolation where the neighbouring points were weighted by the inverse square of the distance. No special attention was paid to the dynamic equilibrium of these re-sampled fields, as the initial state and boundary conditions required for our purpose are a combination of the meso-scale circulation and the tidal dynamics. We acknowledge that ORCA025 is not strictly validated over the continental shelf because it is a global model, not aimed at modelling the shelf ocean. However, the impact of the eastern boundary condition on the simulation is weak because it is entirely located over the shelf. Indeed, the residual circulation in the Channel is eastward, mainly driven by tidal residual currents (Salomon and Breton, 1993), and thus flows outside the model.

In fact, since we focused on the circulation over the shelf, it was crucial to account for tides which play a major role in the mixing of temperature and salinity, through internal tides at the shelf break and bottom friction over the shelf. Thus, as did Lazure and Dumas (2008), the 
barotropic component of the open boundary conditions were obtained by a broader MARS configuration extending from $20^{\circ} \mathrm{W}$ to $10^{\circ} \mathrm{E}$ longitude and from Portugal to Iceland in latitude. This wide 2D model had a grid size of about $5 \mathrm{~km}$ at mid latitude and was forced by the FES2004 solution (Lyard et al., 2006) which provides 14 tidal constituents (M2, S2, K2,

$\mathrm{N} 2,2 \mathrm{~N} 2, \mathrm{O} 1, \mathrm{P} 1, \mathrm{~K} 1, \mathrm{Q} 1, \mathrm{Mf}, \mathrm{Mtm}, \mathrm{Mm}$, Msqm and M4). An inverse barometric correction of sea level is prescribed at its open boundaries from analysed fields of atmospheric pressure taken from the French Meteorological office's model (ARPEGE). Atmospheric pressure gradients are also provided by the same meteorological model and interpolated on the wide 2D model as surface boundary conditions.

This tidal and meteorological signals were linearly added to the mesoscale solution from ORCA025 afterwards. The open boundary conditions were prescribed for this solution using Dirichlet's formulation for sea surface heights and currents. Temperature and salinity were nudged to ORCA025 within a ten-mesh strip along the open boundaries. Within the same strip, there is a dynamic sponge layer where horizontal eddy viscosity is significantly enhanced by a factor of 5 .

\section{Freshwater budget and river flows.}

The rivers flows were prescribed using historical time series at a daily frequency providing by the French freshwater office database (http://www.hydro.eaufrance.fr/). An overview of the main freshwater inputs is given in Table 1. Minor inputs are gathered in this table under the denominations of Northern Brittany, Southern Brittany and Basque Rivers but actually designate a set of 23 rivers, each of which is introduced at the appropriate location.

This table shows that the two major rivers (i.e. Loire and Gironde) account for $75 \%$ of freshwater inputs to the Bay of Biscay and the four main ones for $93 \%$. Nevertheless, diffuse inputs from small rivers are included to make our comparison with coastal salinity probes relevant, as these small catchments do have a local impact.

Concerning the freshwater budget, neither evaporation nor precipitation have been taken into account in this application because of the great uncertainties of the analysed precipitation in atmospheric model (evaporation has been taken into account for the heat budget through the latent heat flux). The salinity distribution is therefore governed by the river inputs, open boundary conditions, circulation and mixing.

\section{Model spin up}

Two points condition the spin-up phase. First, the initial conditions are not in a dynamic equilibrium because of the way they are constructed (i.e., due to the interpolation scheme and linear fusion of tidal and ORCA solution), so that fast gravity waves are generated in the early steps of the simulation. But as long as their phase speed is very high, the time needed to radiate them away is very small with respect to the time scale considered here (annual to semi-decadal).

Secondly, over the shelf temperature and salinity are not distributed in a relevant way if the ORCA solution from which the initial hydrology is inferred does not account for tidal mixing or a realistic chronology of the rivers' runoff. The latter has a more lasting effect. The different numerical experiments showed that, over the shelf, the initial hydrology has an influence over the solution (river plumes and surface mixed layer) especially during the first year. But after the first year, the solution is no longer dependent on the initial state. Thus, none of the results presented below include this first spin-up year. 


\section{The observations}

Scores of simulations were assessed through intensive comparison to observations. This part of the paper presents the data set from which the model's performances were evaluated.

The climatology (Vandermeirsch et al., 2008, http://www.ifremer.fr/climatologiegascogne/index.php) is based on a data set collected over a region that extends from $15 \mathrm{~W}$ to $1 \mathrm{~W}$ and $43^{\circ} \mathrm{N}$ to $50^{\circ} \mathrm{N}$ of about 100,000 temperature and/or salinity profiles from 1862 to 2006. Most of the data (about $90 \%$ ) are dated from 1960 on. Temperature and salinity profiles taken near the main estuaries were not used due to their high spatial and temporal variability. This means that stations where salinities were less than 20 psu have been excluded from the analysis. This original climatological approach relies on an optimal estimation that accounts for the various scales of the processes structuring the hydrological features by choosing an appropriate size of neighbourhood. This climate data provides monthly fields of temperature and salinity at a resolution of a tenth of degree on 261 standard irregularly distributed levels ( $5 \mathrm{~m}$ next to the surface to $100 \mathrm{~m}$ at the bottom) from the surface down to $4,000 \mathrm{~m}$.

A comprehensive data set of CTD casts taken from the SISMER database (www.ifremer.fr/sismer/index FR.htm) was used to compare temperature and salinity simulations in the water column. This data set contains all available data from surveys run between 2001 and 2004 over the shelf.

Sea surface temperature (SST) satellite images from NAR (Near Atlantic Region, zone GASC) were used to compare simulated and observed SSTs. NAR is an OSI SAF (Ocean and Sea Ice Satellite Application Facility, http://www.osi-saf.org/index.php) product that provides SST data. NAR SST comes from the NOAA-18 polar-orbiting satellite (previously NOAA-17 and NOAA-16) whose archive has been available since 2001. The pictures have a spatial resolution of $2 \mathrm{~km}$ and are produced four times a day.

Long time series were collected from salinity probes placed off the coast on the islands of Oléron, Houat and Les Glénan (Lazure et al., 2006) on the Atlantic arc of the Bay of Biscay. Since they are distant from the area impacted by small catchments, they are mostly influenced by large river plumes (i.e. from the Gironde and Loire estuaries). The salinity thus measured showed the chronology of large river plume dynamics passing around these islands. The comparison gives a relevant idea of the transit time of river plumes from the mouth of the estuaries to the probes.

\section{Results}

\subsection{Comparison with climatology}

The simulated variables were averaged monthly from 1999 to 2004 . This modelled climatology was compared to the in situ climatology briefly described above.

Temperature

We focused on a summer month for this, in order to highlight the model's ability to reproduce thermal structures over the continental shelf of the Bay of Biscay. Figure 2 shows the near surface $(5 \mathrm{~m})$ temperature field from climatological data and the model (first computed level) in July. West of Brittany, the thermal front of Ushant is well reproduced, both in its scope and in the order of magnitude of the horizontal temperature gradient. Nevertheless, the modelled 
temperatures appear to be too warm at the entrance of the English Channel. Over the Armorican shelf, the simulated temperatures show good agreement with the climatology : the relatively cooler coastal strip ( 1 to $2{ }^{\circ} \mathrm{C}$ lower) over the Armorican shelf is apparent in both figures. The warm pool in the southern part of the Bay whose extent grows in August is also well reproduced as is the coastal cold water strip along the Landes coast induced by occasional upwellings, although the upwellings' intensity seems weaker in the model. The main discrepancy occurs in the south-western part of the domain along the Spanish coast. While the climatology indicates cool water up to $18^{\circ} \mathrm{C}$, the model shows a slight upwelling tendency which is far from the actual climatology results.

At depths of $70 \mathrm{~m}$ (Figure 3) the main hydrological characteristic is the cold pool over the Armorican shelf. Although the model gives the correct shape of the cold pool, it overestimates the sub-surface temperature by around $1^{\circ} \mathrm{C}$. This difference is not restricted to the shelf but extends over the abyssal plain where the same deviation can be seen. North of the domain, near-bottom predictions at the entrance of the Channel fit the climatology well.

\section{Salinity}

Figure 4 presents both observed and predicted surface salinities in April. This month is representative of the winter and early spring conditions where the river runoffs are at their maximum. The simulated surface salinity shows very similar features to the climate data over the shelf. A low salinity strip bounded by the 35 isohaline extends from the Spanish border to the west of Brittany. The shape of this isohaline over the shelf differs slightly, since it seems to extend further to the north in the climatology than the prediction. The predicted salinities at the mouth of the Gironde and Loire estuaries are lower than those from the climatological records. However, bearing in mind that nearshore CTD profiles were excluded from the dataset used for the climatology set up, these differences can be easily explained. Seaward predicted salinity is less saline than that observed, as shown by the shape of the 35.5 isohaline but the model climatology misfit is always less than $0.5 \mathrm{psu}$. The boundary condition is mostly responsible for this discrepancy because along the boundaries, the model is forced to fit the results of ORCA. Along the western boundary, the shape of the 35.5 psu isohaline reveals that the surface climatological salinity is more saline than ORCA's solution during that period.

The observed and modelled surface salinity in September are shown in Figure 5. At the end of summer, the weakness of runoffs induces a rise in coastal salinity. Meanwhile, the northwestern prevailing winds shift the surface layer to the south-west as described by Lazure and Jegou (1998). As a result, except inside the estuaries, the lowest surface salinities are shifted towards the southern part of the Bay of Biscay. This phenomenon is clearly visible in both the climatology and the simulation. The lowest salinities are located to the south of the Gironde estuary and the 34.5 isohaline is accurately reproduced. Nevertheless, a predicted tongue of less salty ( $<35 \mathrm{psu}$ ) water along the east Spanish coast does not fit the observation.

\subsection{Comparison with in situ data}

In order to compare the modelled results with the quite extensive data set described above, the temperature and salinity is sampled at several standard levels $(5,10,15,20,30,40,50$, $75,100,150,200 \mathrm{~m}$ ) at each profile location (see figure 1). The temporal distribution of the data shows that most of the data was gathered during spring and autumn. Thus, predictions and observations were statistically compared for these two periods of the year, from April to June and October to December. 
Figures 6 and 7 show the comparison for springtime. A very good agreement is reached for salinity prediction (figure 6). The statistics show no bias (<0.1 psu) and beneath the surface where the variability is maximal, the RMSE (Root Mean Square Error) remains weak $(<0.6$ psu at $5 \mathrm{~m}$ ). Below the surface layer and near the bottom it is almost nil because of the very weak seasonal to interannual variability of bottom salinity over the shelf. The agreement is less satisfactory when temperatures are compared (figure 7). Very small biases are observed near the surface $\left(-0.1^{\circ} \mathrm{C}\right)$ and near the bottom. However, a comparison at different vertical locations shows that the model does not reproduce the vertical structure of the temperature accurately. The bias increases, going down from the surface to reach a maximum of $0.9^{\circ} \mathrm{C}$ at $20 \mathrm{~m}$. It decreases monotically to $50 \mathrm{~m}$ and remains weak and stable at deeper depths. This indicates that the modelled sub-surface temperature is too much warmer than the observed one and may result from an overestimation of the deepening of the thermocline. In this region of high vertical gradients, the model fails to accurately represent the exact vertical location of the rising thermocline at this period as it can be observed on the RMS at depths between surface and $30 \mathrm{~m}$. The gradients remain relatively high with values between $0.7^{\circ} \mathrm{C}$ to $1^{\circ} \mathrm{C}$ (this is discussed below).

In autumn the salinity (Figure 8) predictions are as good as in spring: the bias remains very weak and the RMSE drops to 0.2 psu. The temperature (Figure 9) appears too warm in the surface layer with a bias of about $0.8^{\circ} \mathrm{C}$ at $5 \mathrm{~m}$. With depth, it slightly increases to reach $1.2^{\circ} \mathrm{C}$ at $40-50 \mathrm{~m}$ and decreases to $0.1^{\circ} \mathrm{C}$ at $100 \mathrm{~m}$. A slightly negative bias is observed at $200 \mathrm{~m}$ but its statistical significance is low with respect to the number of observations. The RMSE is $0.7^{\circ} \mathrm{C}$ from the surface to $20 \mathrm{~m}$, peaking at $1.2^{\circ} \mathrm{C}$ at $40 \mathrm{~m}$ and going down to $0.5^{\circ} \mathrm{C}$. Again, this increase reveals a problem in simulating the deepening of the thermocline and the breakdown of the stratification at this period of the year. Moreover, the positive biases at each vertical location could be interpreted as an overestimation of the heat content of the water column over the shelf.

\subsection{Sea surface temperature. Seasonal to interannual variability.}

The modelled sea surface temperature and satellite observations were first averaged by month to avoid gaps in daily data due to cloud cover, especially in winter. Observed SSTs were interpolated over the model grid and compared to the simulated temperature of the surface level at each grid point. There were 21,000 wet cells in all. The differences were sorted into 3 classes : between -0.5 to $0.5^{\circ} \mathrm{C}$, over +0.5 (i.e., warmer model) and below -0.5 (i.e., cooler model). The first class corresponds to the order of magnitude of precision as satellite SSTs. Figure 10 presents the results from 2001 (the first data available from NAR) to 2004. Statistics have also been presented for the shelf (depth less than 200m) and the deep ocean (depths $>200 \mathrm{~m}$ ). It can be observed that during the entire assessment, more than $50 \%$ of the differences lie in the first class. During early spring, i.e., February to April, this percentage can exceed $85 \%$.

The remaining curves reflect a difference of more than $0.5^{\circ} \mathrm{C}$ with slight seasonal signals. From June to October, the percentage of predicted SSTs that are more than $0.5^{\circ} \mathrm{C}$ cooler rises. These results are not in contradiction with in situ data comparisons next to the surface, as long as the statistics presented encompass the whole Bay of Biscay, including the abyssal plain which accounts for half of the total domain.

Over the shelf, the overall prediction is worse than for the whole Bay of Biscay. The positive shifts increase each year at the end of the summer to reach a relative maximum in OctoberNovember. The number of grid cells over the shelf which exceed $0.5^{\circ} \mathrm{C}$ was the highest in autumn 2003. The role of the exceptionally hot summer of 2003 is not clear. It seems that the effect of this warming decreases until spring 2004.

Over the deep bay, the overall assessments shows that, on average, $75 \%$ of the differences between model and observation lie within the limit of -0.5 to $+0.5^{\circ} \mathrm{C}$. The positive and negative shifts do not show any clear trends and remain at the same level except during 
summer and autumn 2002, where the model was cooler than observations over half of the deep Bay.

Figure 11 illustrates the SST patterns in July 2002 and the differences between model and measurement. The most important discrepancies are located to the east of $6^{\circ} \mathrm{W}$ and the predicted SSTs are cooler from the south of Brittany to the coast of Spain. The underestimations of SST reach $1.5^{\circ} \mathrm{C}$ over the shelf off the Landes coast. The vertical resolution over great depths is probably insufficient to accurately reproduce the summer warming (the warm pool) described previously by Koutsikopoulos and Le Cann (1996). To the west and north of Brittany, the model behaves differently, overestimating the SST by $1^{\circ}$ to $1.5^{\circ} \mathrm{C}$. This location coincides with the thermal front of Ushant.

In September 2003 (Figure 12), the warmer area extends over the Armorican shelf and at the entrance of the Channel, whereas the cool area shrinks. The overestimation can reach $2^{\circ} \mathrm{C}$ in places. Most of the warmer predicted SSTs are located over the shelf north of $46^{\circ} \mathrm{N}$. The southern part of the Bay and its South-east corner are well predicted and in accordance with the comparison of climatology and the warm pool (Koutsikopoulos and Le Cann, 1996) is well reproduced.

\subsection{Salinity. Seasonal to inter annual variability}

The model's accuracy in simulating salinity variations over the shelf was assessed by comparing model predictions with salinity measurements near two islands. Model results have been filtered from tide and an output has been performed every 3 days. Figure 13 shows the comparison with measurements taken in the Glénan archipelago and Oléron islands (see locations in Figure 1) and the Loire and Gironde river runoffs during the same period. General agreement at both stations can be noted. Oléron, which is located closer to the mouth of the Gironde than the Glénan site to that of the Loire, shows the largest variations with intermittent decay of coastal salinity to 29 psu. The model fits the observations well over both time and amplitude during these events. A mean time-shift of one week to 10 days is observed between Gironde flooding and the drop in salinity. During summer time, the decrease in river runoff leads to an increase in salinity which is reproduced, although the model had some difficulty in reproducing the observed high coastal salinities. The observations show a mean salinity of $35 \mathrm{psu}$ in summer, while predicted salinities hardly reached 34.5 psu. At the Glénan location, time series of observed and predicted salinities are also in rather good agreement. The discrepancies seen during the second half of 2001 are likely due to spurious measurements. The salinity at Glénan begins to decrease in summer, when runoffs are at their minimum. Moreover, some fortnightly to weekly measurements from the Rephy network at a nearby station (less than $5 \mathrm{~nm}$ ) do not confirm the relatively low salinity of 33 to 34 psu measured at the Glénan location. We therefore conclude that these measurements present too many doubts and were not suited for comparison during that period. During summer, the model is able to reproduce the high coastal salinity of 35 psu quite accurately.

\section{Discussion and concluding remarks}

This paper investigates the hydrology simulated by the MARS model in the Bay of Biscay and its extension to the western Channel. After a 1 year spin-up period, the model was run for 6 years without any relaxation to the data, except near the boundaries. The consistency of simulated salinity and temperature fields was first assessed through comparisons with climatological data for summer. Then analysis focused on the French continental shelf and used in situ measurements to depict the accuracy of the model in reproducing the vertical 
distribution of both temperature and salinity Quantitative validation of the sea surface temperature from NAR measurements for the period 2001-2004 over the whole domain have completed the analysis. Lastly, costal salinities have been assessed by comparison with in situ measurements. The main results can be summarised as follows :

The model reproduces observed salinities accurately, both from a climatological point of view and from time trends along the coast: the transient decays of salinity due to floods of the main rivers were properly reproduced both in time and magnitude. Over the shelf, the magnitude of salinity compares very well with the data: no bias is observed, and the error remains low (RMSE < $0.6 \mathrm{psu}$ ) at the surface, where the salinity variability develops.

However, some model-data misfits can be highlighted, like an underestimation of surface salinity and a questionable salinity tongue along the Spanish coast in September which is not apparent from the climatological data.

Good overall agreement in reproducing SST is reached. Over more than half of the domain, the SSTs are reproduced within a deviation of the order of magnitude of the measurements' precision $\left( \pm 0.5^{\circ} \mathrm{C}\right)$, whatever the season. Over the shelf, a global overestimation (between 0.5 to $1^{\circ} \mathrm{C}$ ) of the temperature from surface to bottom is shown by comparisons with climate data, in situ and satellite measurements.

Lastly, the predicted surface salinities fit well with observations, both over the shelf as shown by comparison with in situ data and along the coast. The underestimation of salinity during summer at Oléron must be investigated. Again, it is likely that the vertical mixing is the main cause of discrepancy.

Some causes of these discrepancies can be ruled out. For instance, the effect of spurious initial conditions cannot be put forward as was done by Young et al (2004) because some experiments were done using various initial conditions from climatology or ORCA results without any significant influence after one year of spin up. Thus, a one year spin up (year 1998 ) is long enough for the model to forget the initial conditions over the shelf. Moreover, open boundary conditions are unlikely to be incriminated since the temperatures at the western boundary were in good accordance with observations. Again, some experiments using temperature at open boundaries from the climatology did not show any significant changes in the predicted temperature over the shelf during the 6-year simulation.

Overestimation of SST over a shelf is a rather common discrepancy of models. Very similar conclusions were reached by Holt and James (2006) in their study of temperature trends on the western shelf of Great Britain. Although their resolution was finer $(1.8 \mathrm{~km})$ and their turbulence closure scheme different (Mellor Yamada level 2.5), they observed an overestimation of SST in late summer, in comparison with remote sensing data. Modelling studies of the North Sea (Holt and James, 1999; Luyten et al., 2003) have also drawn similar conclusions. From the above-mentioned literature, the main causes of discrepancies could be due to the heat flux calculation and turbulence closure. Luyten et al (2003) put forward an influence of the heat budget calculation through the sensible and latent heat fluxes. In this modelling study, classical bulk formulations were used and the wind speed increased by $25 \%$ in the formulation of latent heat. However, the positive biases revealed at all levels show that the heat content is always greater than in reality.

It can be seen that the depth of maximum RMSE deepens from spring $(20 \mathrm{~m})$ to autumn $(40 \mathrm{~m})$, following the deepening of the thermocline during that period of time. This suggests that the turbulence parameterisation could be the second cause of discrepancy in the vertical distribution of temperature. Like Holt and James (2006), we assume that an underestimation of the vertical mixing is the main cause of the overestimation of the SST at the end of the summer. The underestimation of surface salinity during summer could also reveal a lack of 
mixing of the surface layer. A recent study on the internal mixing of the seasonal stratification in the Celtic sea (Palmer et al., 2008) highlights the role of internal tides and near-inertial waves. These effects have not been explicitly considered in the parameterisation of the model mixing and will be considered in the future.

These discrepancies may affect the circulation over the shelf to an extent which needs to be quantified. As shown recently (Lazure et al., 2008), the breakdown of the stratification and the rising of the strong bottom front may induce an autumnal current on the shelf. These kind of currents observed around British Isles were also recently described by Hill et al. (2008). But a precise simulation of the formation of this bottom current requires more accurate mixing during this crucial period.

However, despite its shortcomings, the global ability to reproduce observed hydrology led us to run the model in an operational system in the Previmer project (www.previmer.org). Some slight changes from the configuration described above have been implemented. First, the open boundary conditions are no longer provided by the ORCA configuration, which is not an operational model. Mercator fields provided by the PSY2V2 configuration (Drillet et al, 2005) are being used in addition to tidal boundary conditions provided by MARS2D model described above. From 2007, the results presented on the PREVIMER web site use climatological temperature and salinity fields and barotropic conditions taken from a coarser 2D MARS configuration at the open boundaries. The river runoffs are the same but only the main rivers (Adour, Gironde, Loire and Vilaine) are updated daily. Otherwise, monthly averaged values from several decades (depending on the length of archives) are imposed. As shown by Siddorn et al. (2007), the use of climatological values for river runoff can significantly alter the quality of the results. In the case of the Bay of Biscay, $93 \%$ of the total amount of fresh water is updated daily and it is expected that the interannual variability is correctly recorded.

\section{Acknowledgements}

This work received financial support from by Previmer (French coastal operational oceanography project) and by the project HABIT (Harmful Algae in Thin Layers) funded under the EU Sixth Framework Programme; Priority 1.1.6.3 (Global Change and Ecosystems). The authors thank S. Michel (Ifremer/Dyneco) and A.M. Tréguier (CNRS/LPO) for providing ORCA results. Finally, we thank the two referees for their careful reading of the draft and their useful suggestions for improvement.

\section{References}

Barnier, B., G. Madec, T. Penduff, J.M. Molines, A.M. Treguier, J. Le Sommer, A.Beckmann, A. Biastoch, C. Boning, J. Dengg, C. Derval, E. Durand, S. Gulev, E. Remy, C. Talandier, S. Theetten, M. Maltrud, J. McClean, B. De Cuevas 2006: Impact of partial steps and momentum advection schemes in a global ocean circulation model at eddy permitting resolution. Ocean Dynamics, DOI: 10.1007/s10236-006- 0082-1.

Cabanas, J.M., Lavin A., Garcia M.J., Gonzalez-Pola C., Tel Pérez, E., 2003, Oceanographic variability in the northern shelf of the Iberian Peninsula, 1990-1999. ICES Mar. Sci. Symp., 219, 71-79. 
Crosnier L., Le Provost C., 2007. Inter-comparing five forecast operational systems in the North Atlantic and Mediterranean basins: The MERSEA-strand 1 methodology. J. Mar. Sys., $65,354-375$.

Drillet, Y., Bourdallé-Badie, R., Siefridt, L., Le Provost, C., 2005. Meddies in the Mercator North Atlantic and Mediterranean Sea eddy-resolving model. Journal of Geophysical Research 110, C03016. doi:10.1029/2003JC002170.

Friocourt Y., Levier B., Speich S., Blanke B. and Drijfhout S.S. 2007 Journal of Geophysical research, 112, C09008, doi:10.1029/2006JC003935,

Froidefond, J.M., Castaing, P., and Jouanneau, J.M.1996. Distribution of suspended matter in a costal upwelling area. Satellite data and in situ measurements. Journal of Marine Systems, 8, 91-105.

Gaspar J.P., Grégoris U., Lefèvre J.M. 1990. A simple eddy kinetic energy for simulations of oceanic vertical mixing: test at station papa and long term upper ocean study site. Journal of Geophysical Research, 95 (C9), 16179-16193.

Gill, A. E.. 1982. Atmosphere-ocean dynamics. Academic Press, Orlando FL, 662 pp.

Gonzalez, M, Ferrer, L, Uriarte, A, Urtizberea, A, Caballero, A. 2008. Operational Oceanography System applied to the Prestige oil-spillage event. J. Mar. Syst., 72, no. 1-4, 178-188.

Hill A. E., Brown J., Fernand L.,Holt J., Horsburgh K.J., Proctor R.,Raine R., Turrell W. R.,2008. Thermohaline circulation of shallow tidal seas, Geophys. Res. Lett., 35, L11605, doi: 10.1029/2008GL033459.

Holt J.T., James I.D., 1999. A simulation of the Southern North Sea in comparison with measurements from the North Sea Project. Cont. Shelf. Res., 19, 1087-1112.

Holt, J.T., James, I.D., 2006. An assessment of the fine scale-eddies in a high resolution model of the shelf seas west of Great Britain. Ocean. Mod., 13, 271-291.

Koutsikopoulos C, Le Cann B., 1996. Physical processes and hydrological structures related to the Bay of Biscay anchovy. Sci Marina, 60, 9-19.

Laubier, L, Le Moigne, M, Flammarion, P, Thybaud, E, Cossa, D., 2004. The monitoring programme of the ecological and ecotoxicological consequences of the "Erika" oil spill . Aquatic Living Resources [Aquat. Living Resour.]. Vol. 17, no. 3, pp. 239-241. Jul-Sep 2004.

Lazure P., Dumas F., 2008. An external-internal mode coupling for a 3D hydrodynamical model at regional scale (MARS). Adv. Wat. Res., 31, 233-250.

Lazure, P., Jegou, A.M., 1998. 3D modelling of seasonal evolution of Loire and Gironde plumes on Biscay Bay continental shelf. Oceanological Acta 21 (2), 165-177.

Lazure P., Jegou AM, Kerdreux M., 2006. Analysis of salinity measurements near islands on the French continental shelf of the Bay of Biscay. Scienca Mar., 70 Suppl. 1 7-14.

Lazure P., Dumas F., Vrignaud C., 2008. Circulation on the Armorican shelf (Bay of Biscay) in autumn. Journal of Marine Systems, 72, 218-237 
Le Boyer A., Cambon G., Daniault N., Herbette S., Le Cann B., Marié L., Observations of the Ushant tidal front in September 2007. 2008. submitted to CSR (this issue)

Le Cann, B., 1990. Barotropic tidal dynamics of the Bay of Biscay shelf: observations, numerical modelling and physical interpretation. Continental Shelf Research 10, 723-758.

Llope M., Anadon R., Viesca L., Quevedo M., Gonzallez-Quiros R., Stenseth N.C. 2006. Hydrography of the southern Bay of Biscay shelf-break region : Integrating the multiscale physical variability ober the period 1993-2003. J. Geophys. Res., 111,C09021,doi : 10.1029/2005JC002963.

Luyten P.J. and De Mulder T., 1992. A module representative surface fluxes of momentum and heat. Technical report N9 MAST-0050-C (Mumm) 30pp.

Luyten PJ, Jones JE, Proctor R, Tabor A, Tett P, Wild-Allen K. 1999. COHERENS: a coupled hydrodynamical-ecological model for regional and shelf seas: user documentation.

Luyten P.J. , Jones, J.E., Proctor, R., 2003 A numerical study of long and short term temperature variability and thermal circulation in the North Sea. JPO, 33, 37-56.

Lyard, F., Lefevre, F., Letellier, T., and Francis, O., 2006. Modelling the global ocean tides: modern insights from FES2004. Ocean Dynamics, 56:394-415, doi:10.1007/s10236-0060086-x.

Madec G, 2008: NEMO ocean engine. Note du Pole de modélisation, Institut Pierre-Simon Laplace (IPSL), France, No 27 ISSN No 1288-1619. Available at www.nemo-ocean.eu

Michel, S., A.M. Treguier and F. Vandermeirsh, 2008. Temperature variability in the Bay of Biscay during the past 40 years, from an in situ analysis and a 3D global simulation, 2008. Submitted to CSR (this issue).

New, A.L., 1988. Internal tidal mixing in the Bay of Biscay. Deep Sea Research, 35, 691709.

Pairaud, I.L., Lyard, F., Auclair, F., Letellier T. and Marsaleix P.. 2008a Dynamics of the semi-diurnal and quarter-diurnal internal tides in the Bay of Biscay. Part 1: Barotropic tides, Continental shelf Research, In Press doi:10.1016/j.csr.2008.03.004

Pairaud, I.L., Auclair, F., Lyard, F., Marsaleix, P., Pichon, A., 2008b. Dynamics of the semidiurnal and quarter-diurnal internal tides in the Bay of Biscay. Part 2: baroclinic tides. Continental Shelf Research, Under Revision.

Palmer, M. R., T. P. Rippeth, and J. H. Simpson, 2008. An investigation of internal mixing in a seasonally stratified shelf sea, J. Geophys. Res., doi:10.1029/2007JC004531, in press.

Payne R., 1972. Albedo of the sea surface, Journal of Atmospheric science, 29, 959-970

Pichon A., Corréard S. 2006. Internal tides modelling in the bay of Biscay. Comparisons with observations. Scientia Marina 70S1, 65-88.

Pingree, R.D., Mardell, G.D., Holligan, P.M., Griffiths, D.K.,Smithers, J., 1982. Celtic Sea and Armorican current structure and the vertical distributions of temperature and chlorophyll. Continental Shelf Research 1, 99-116. 
Pingree, R.D., Le Cann, B., 1989. Celtic and Armorican slope and shelf residual currents. Continental Shelf Research 23, 303-338.

Pouliquen S., A. Lavin, 2006. IBI-ROOS Plan.

http://www.ibi-roos.eu/publications/Pub 24IBI ROOSplan.pdf

Puillat I., Lazure P., Jégou A.M., Lampert L., Miller P.I. (2004) Hydrographical variability on the French continental shelf in the Bay of Biscay, during the 1990's . Cont. Shelf Res., 10, 1143-1163.

Reed R.K., 1977. On estimating insolation over the ocean. Journal of physical oceanography, 7, 482-485.

Salomon J.C., Breton M., 1993. An atlas of long-term currents in the Channel. Oceanologica Acta, 16, 439-448.

Siddorn, J.R., Allen I., , Jerry C. Blackford J.C., Gilbert,F.J., Holt, J.T. Holt M.W., Osborne, J.P., Proctor, R., Mills. D.K. 2007. Modelling the hydrodynamics and ecosystem of North West European shelf for operational oceanography. J. Mar. Sys., 65, 417-429.

Smagorinsky, J., 1963. General circulation experiments with the primitive equations. MonthlyWeather. Review. 91, 99-164.

Vandermeirsch F., Charraudeau R., Bonnat A., Fichaut M., Maillard C., Gaillard F. and Autret E. 2008. Bay of Biscay's temperature and salinity climatology. XI international symposium on oceanography of the Bay of Biscay, Poster session. San Sebastian.

Vincent, A., Kurc, G., 1969. Hydrologie, variations saisonnières de la situation thermique du Golfe de Gascogne en1967. Revue des Travaux l'Institut des pêches Maritimes 33 (1), 7996.

Young E.F., Brown J., Aldridge J.N., Horsburg K.J., Fernand L., 2004. Development and application of a three-dimensional baroclinic model to the study of the seasonal circulation in the Celtic Sea. Cont. Shelf., Res., 24, 13-36. 


\begin{tabular}{|c|r|}
\hline Name of river or & $\begin{array}{r}\text { Annual mean } \\
\text { runoff in cubic } \\
\text { metres per }\end{array}$ \\
\hline group of rivers & 35 \\
\hline Southern Brittany & 60 \\
\hline Vilaine & 70 \\
\hline Loire & 850 \\
\hline Gironde & 885 \\
\hline Adour & 315 \\
\hline Basque rivers & \\
\hline
\end{tabular}

Table 1. Annual mean runoff of major rivers. 


\section{Figures}

Figure 1: Bathymetry of the Bay of Biscay (depth contours in meters) and locations of in situ measurements used for comparison. Black dots indicate the location of salinity measurements at Glénan and Oléron. Locations of CTD casts in autumn are shown with stars, in spring with open circles.

Figure 2: Temperature in July at $5 \mathrm{~m}$ from climatological data (left) and model (right)

Figure 3: Temperature in July at $70 \mathrm{~m}$ from climatological data (left) and model (right)

Figure 4: Salinity at $5 \mathrm{~m}$ in April from climatological data (left) and model (right)

Figure 5: Salinity at 5m in September from climatological data (left) and model (right)

Figure 6: Statistical comparison of observed and predicted salinities at different vertical locations during spring. Upper panel: number of available observations. Middle panel: mean error (bias). Lower panel: RMS error.

Figure 7: Statistical comparison of observed and predicted temperature at different vertical locations during spring. Upper panel: number of available observation. Middle panel: mean error (bias). Lower panel: RMS error.

Figure 8: Statistical comparison of observed and predicted salinities at different vertical locations during autumn. Upper panel: number of available observations. Middle panel: mean error (bias). Lower panel: RMS error.

Figure 9: Statistical comparison of observed and predicted temperatures at different vertical locations during autumn. Upper panel: number of available observations. Middle panel: mean error (bias). Lower panel: RMS error.

Figure 10: Comparison between SST prediction and observations in percentage of total number of pixels over the whole domain (top), over the shelf (middle) and over the deep ocean (bottom).

Figure 11: averaged satellite SSTs in July 2002 (left) and difference between model prediction and satellite data (right)

Figure 12: averaged satellite SSTs in September 2003 (left) and difference between model prediction and satellite data (right)

Figure 13: comparison between simulated salinity (continuous line) and measurements (dashed line from coastal probes and black squares from Rephy measurements). Bottom panel at Glénan, Middle panel at Oleron island. Top panel: Loire and Gironde runoffs. 


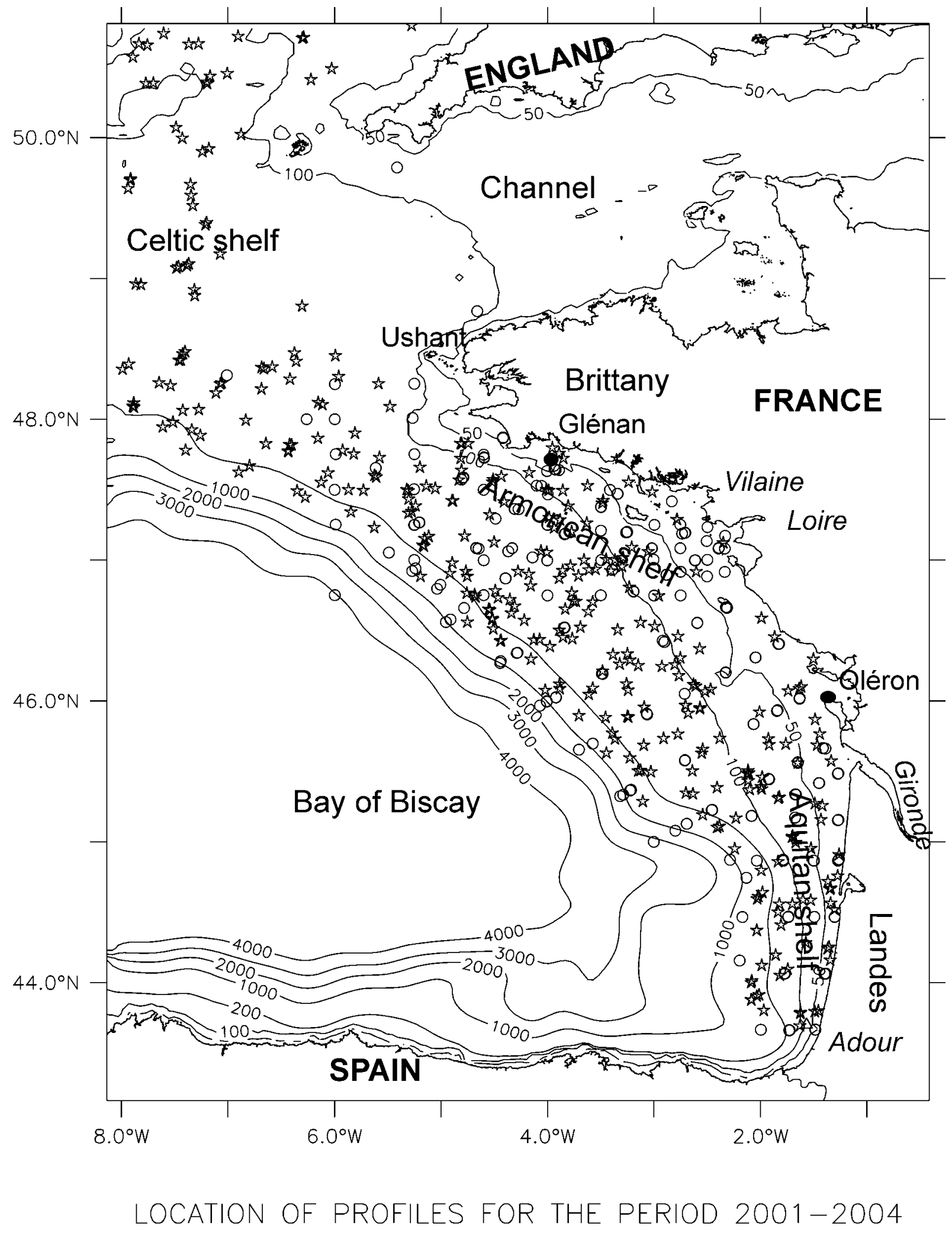

Figure 1 

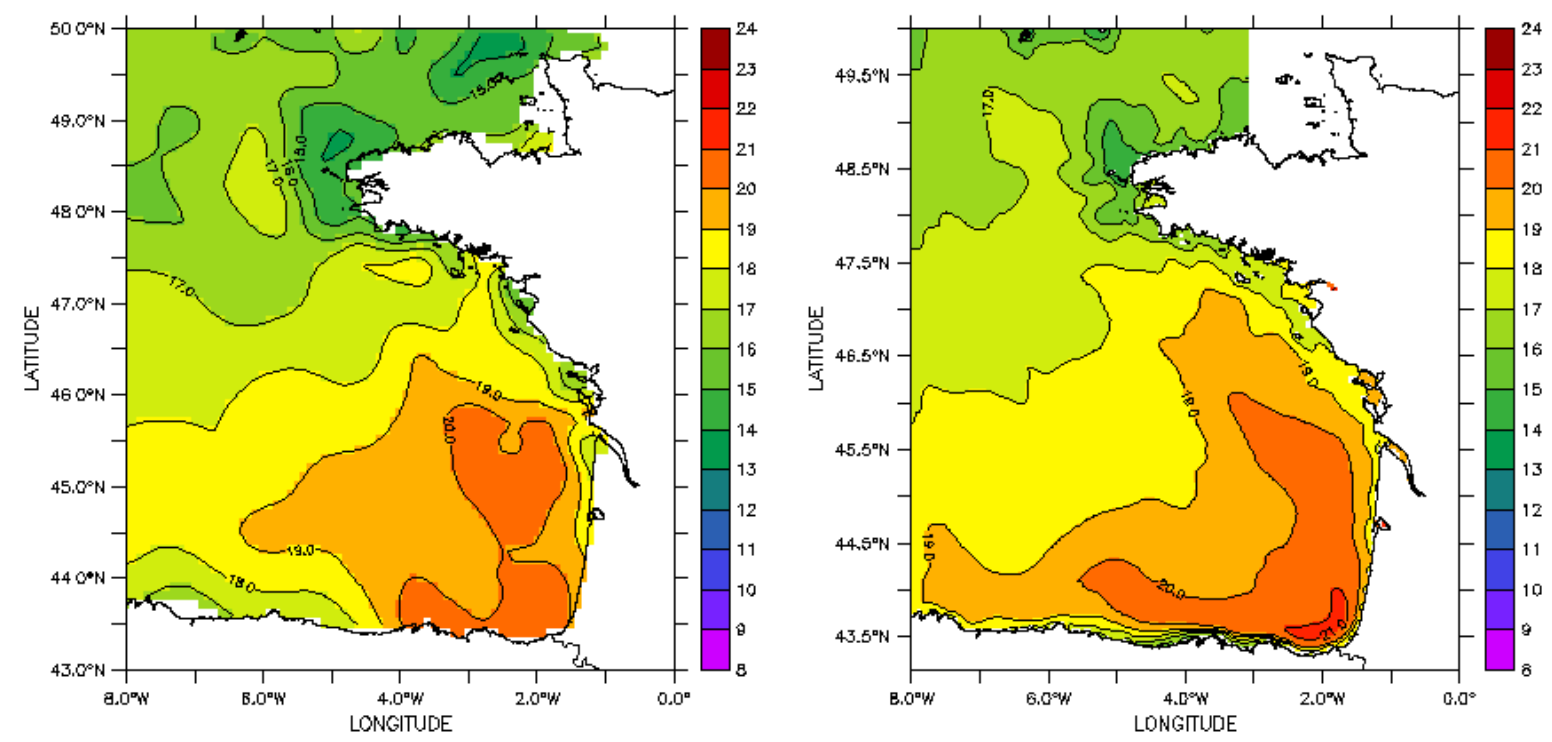

Figure 2
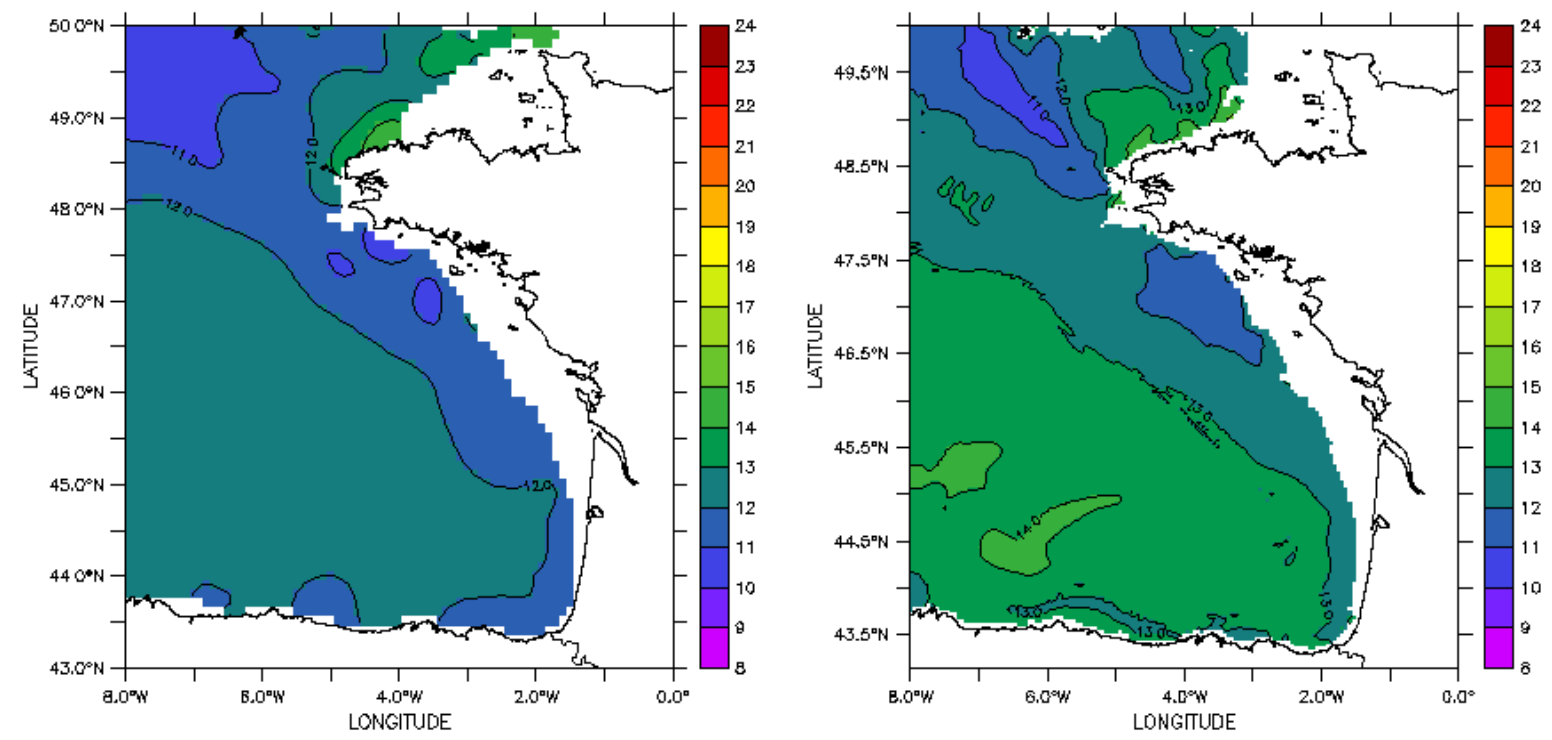

Figure 3 

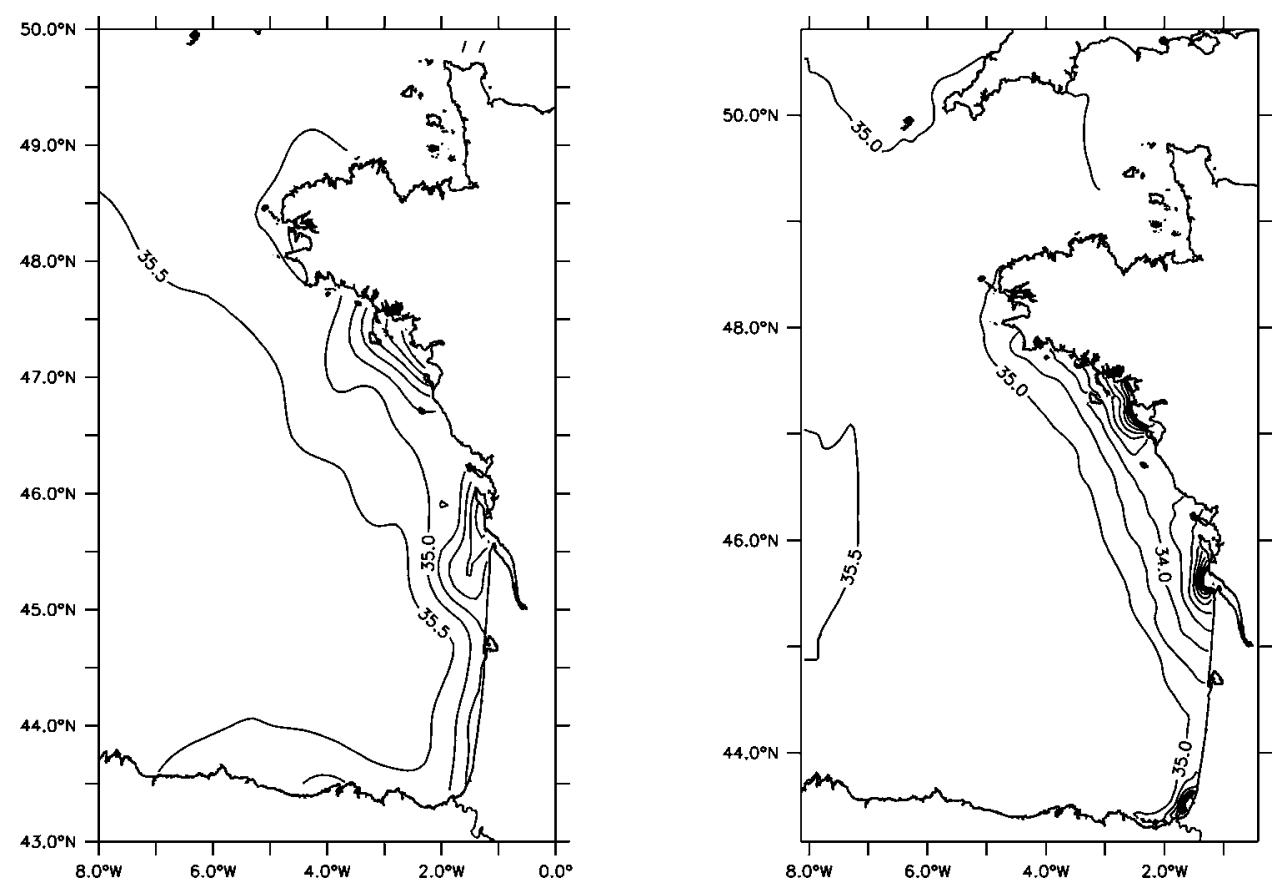

Figure 4
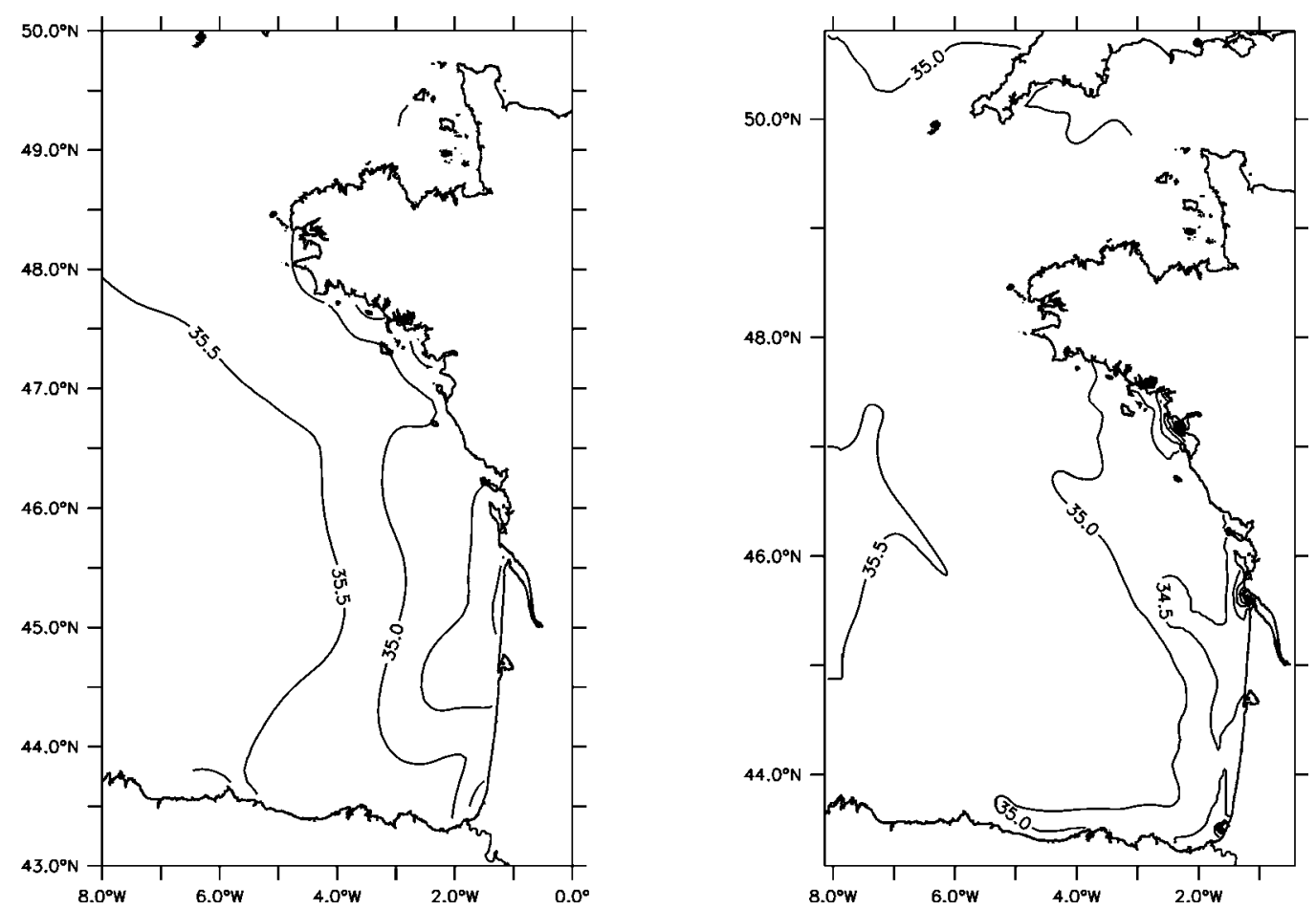

Figure 5 

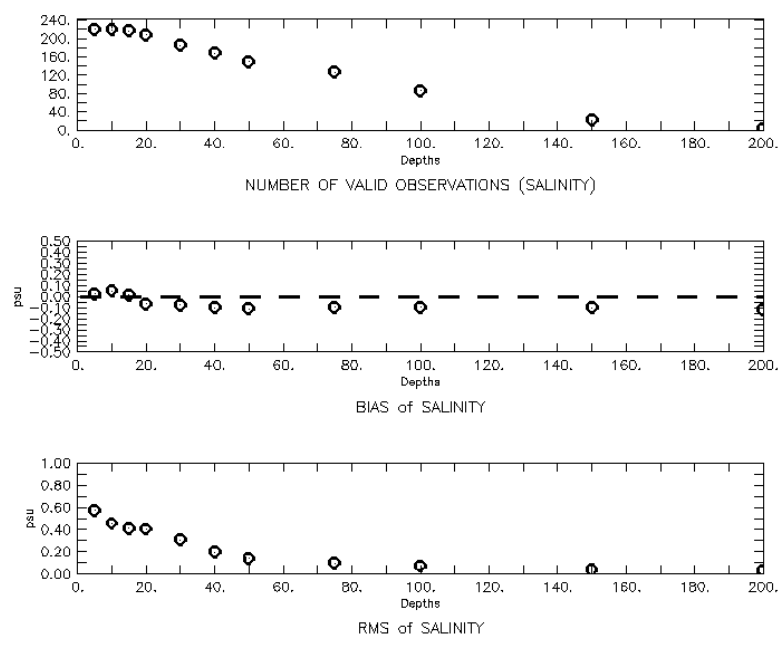

Figure 6
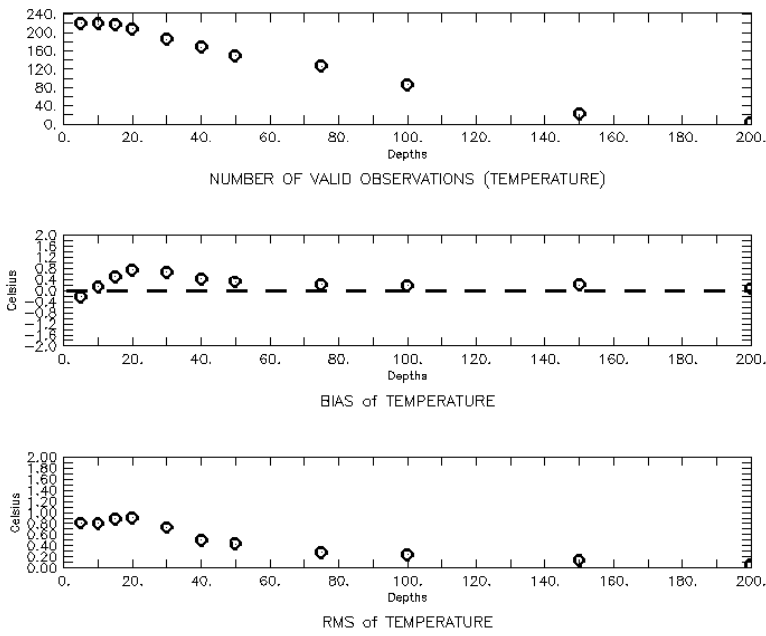

Figure 

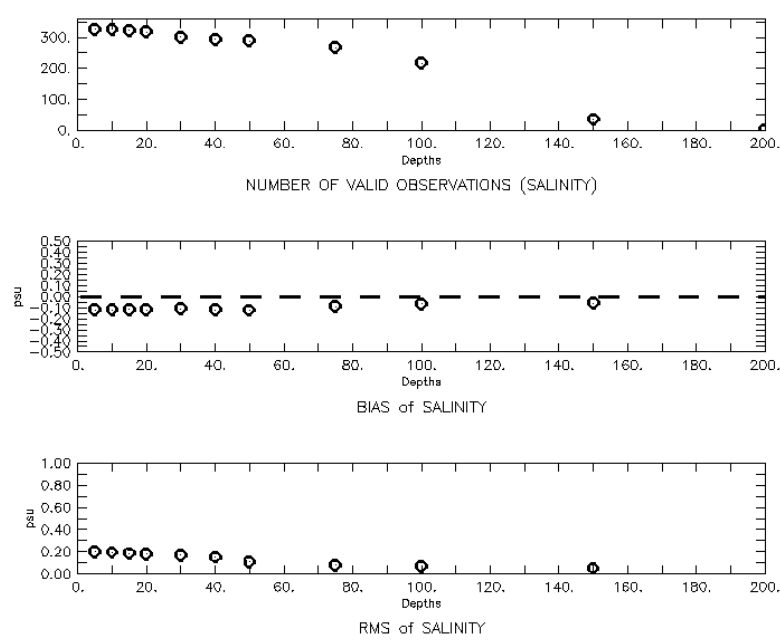

Figure 8
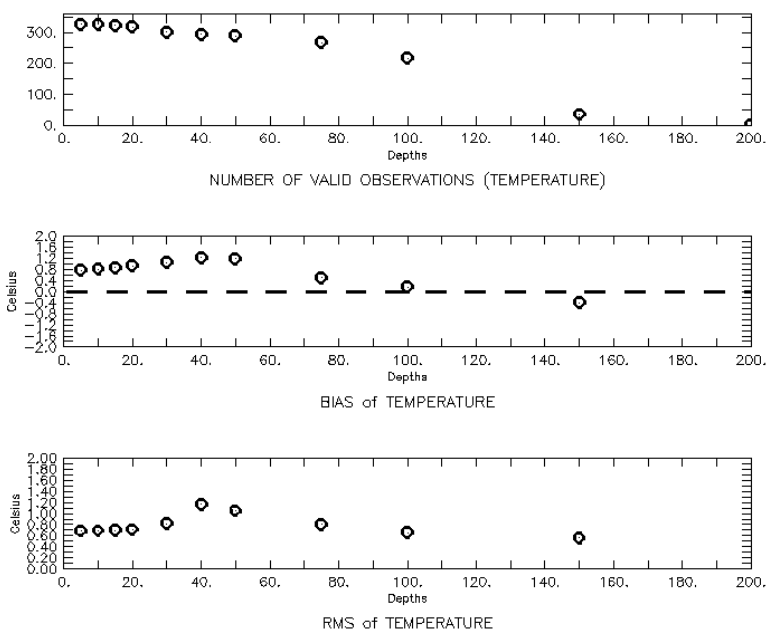

Figure 9 

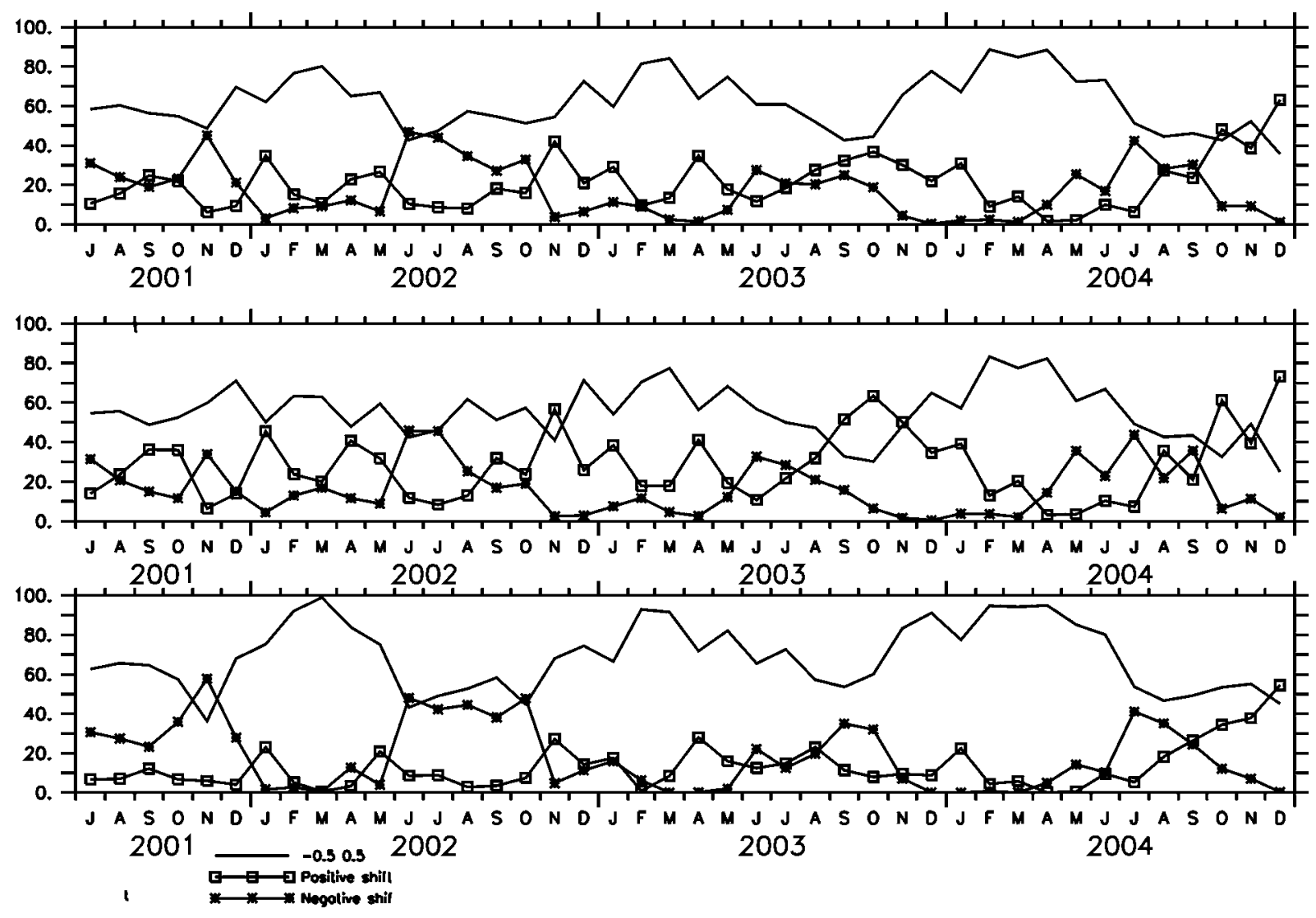

Figure 10
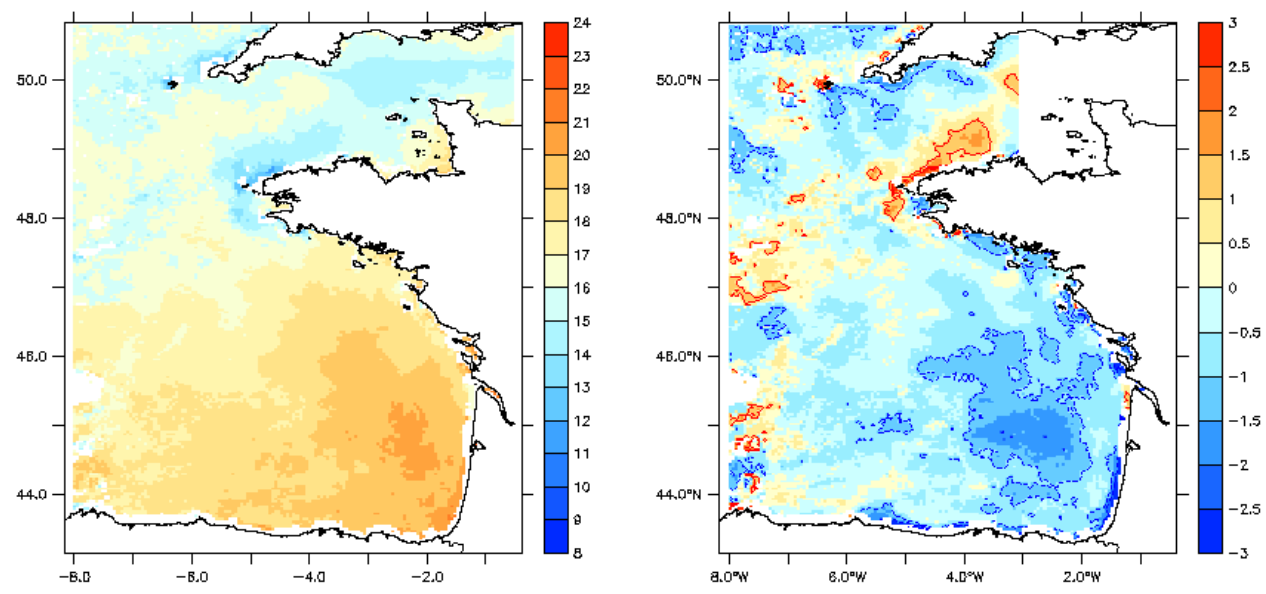

Figure 11 

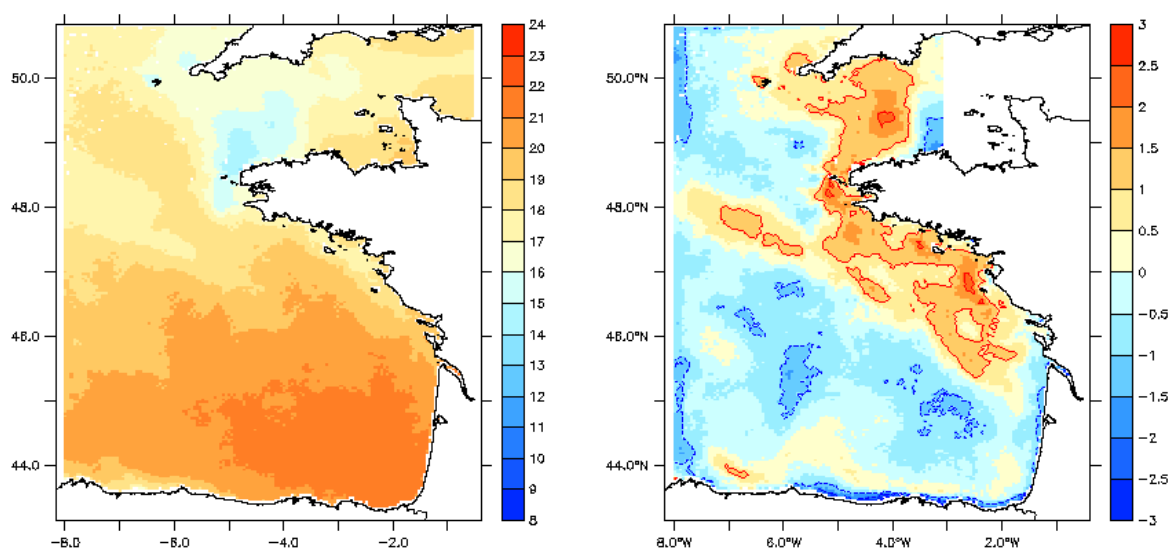

Figure 12 

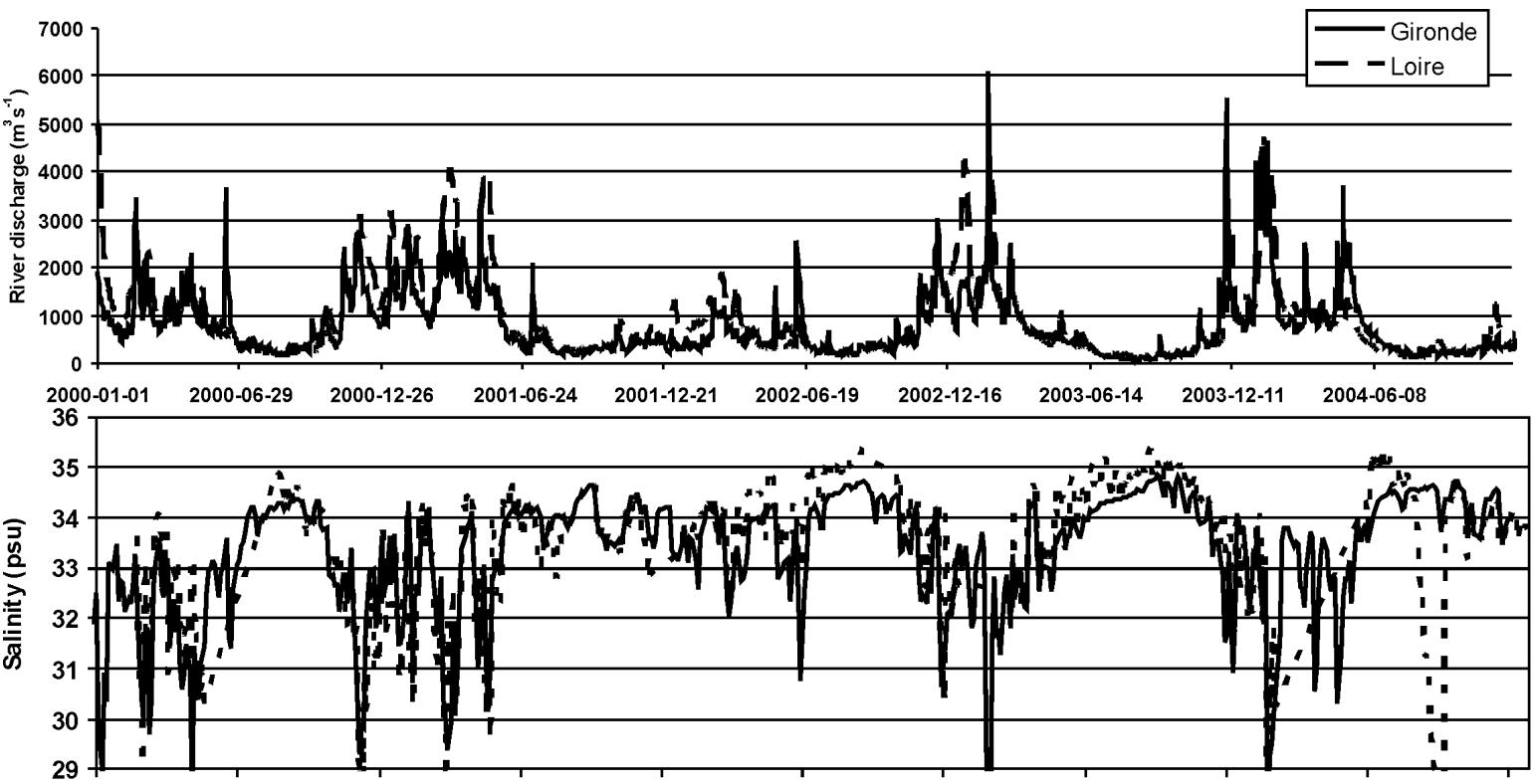

2000-01-01 2000-06-29 2000-12-26 2001-06-24 2001-12-21 2002-06-19 2002-12-16 2003-06-14 2003-12-11 2004-06-08 2004-12-05

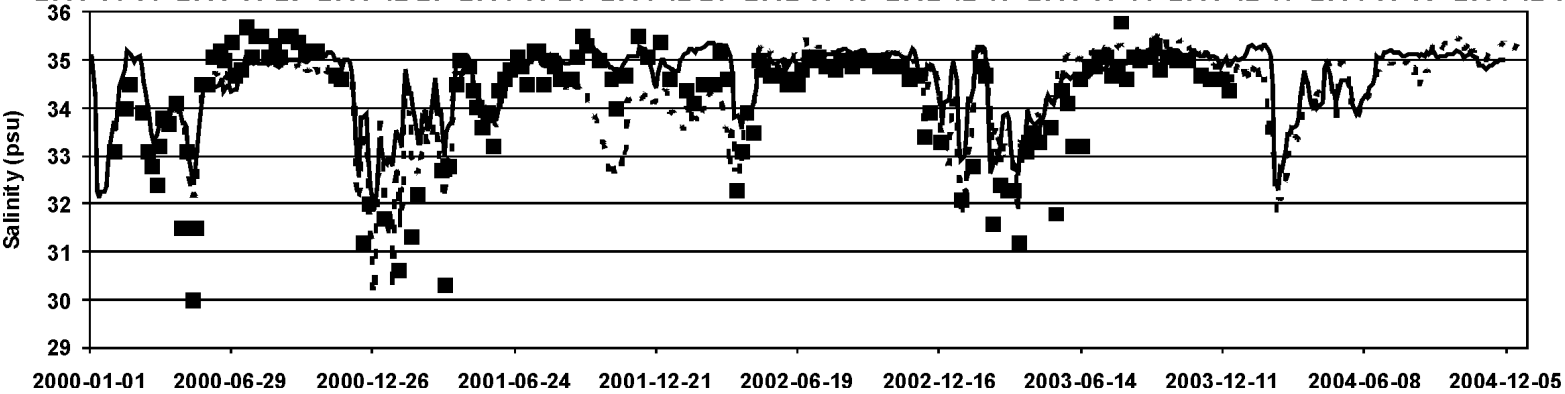

Figure 13 